\title{
Implementation of Accounting in Improving the Financial Statements Quality of Islamic Boarding School in Indonesia
}

\author{
Dewi Kirowati ${ }^{1}$, Shinta Noor Anggraeny ${ }^{2}$, RB. Iwan Noor Suhasto ${ }^{3}$ \\ State Polytechnic od Madiun, Jalan Serayu No. 84 Madiun, East Java, Indonesia ${ }^{1,2,3}$ \\ \{dewik@pnm.ac.id $\left.{ }^{1}\right\}$
}

\begin{abstract}
The emergence of the IBS Accounting Guidelines that were effectively used in 2018, has greatly helped Islamic Boarding School (IBS) in Indonesia in preparing financial reports. Based on the data base for IBS in the Ministry of Religion, until 2019 there are 29 IBS with approximately 7700 students. IBS are non-profit organizations, namely organizations that obtain their own capital or fund capital by increasing the surplus, accepting donations or donations from individuals or community groups. This study aims to determine the extent to which the implementation of IBS accounting guidelines in improving the quality of financial reports of the Al-Mujaddadiyyah Islamic Boarding School. This type of research is qualitative research, using descriptive methods. Data presented in descriptive form without being processed with data reduction analysis techniques, data presentation, and drawing conclusions. With this research, it is expected to obtain information about preparing IBS financial reports according to standards, namely the IBS Accounting Guidelines.
\end{abstract}

Keywords: Islamic Boarding School Accounting Guidelines, Financial Reports, Islamic Boarding School

\section{Introduction}

In Indonesia, the development of Islamic Boarding School (IBS) is increasing rapidly and there is no doubt that IBS have a real contribution to the development of education. IBS have experience in fostering and developing communities and are able to increase their role independently by exploring the potential of the community.

IBS are religious-based educational institutions that are known as independent institutions as well as being role models in life. Apart from that, IBS have been known to be places to forge students who are noble, virtuous, tenacious, honest, and hardworking. Based on the role of IBS education which develops the independence and economy of the boarding school, it is time for the boarding school to have a vacation to increase the boarding school income and provide provisions for students to do business or do entrepreneurship.

According to the minister of industry, Airlangga Hartanto, the 4.0 industrial revolution because all this time IBS have played a role in encouraging economic growth, that is, some 
have established cooperatives and business incubators in the fields of trade, agriculture, fisheries, livestock and others [1].

Currently the Ministry of Industry is initiating a new entrepreneurial growth program to improve the competence of human resources, especially in the IBS environment through the Santri-preneur program as a way to make it into the top 10 in 2030. The santri-preneur program states that today's students are required not only to study religion but also to be able to be entrepreneurial.

In addition, in developing the economic independence of IBS, namely to support IBS as the basis for Indonesia's economic flow, Bank Indonesia has prepared three programs (1) developing various potential business units that take advantage of cooperation among boarding school, (2) encouraging collaboration between IBS through the virtual markets provision. IBS business products as well as business matching, (3) developing boarding school holding and preparing IBS financial report standardization with IBS accounting system used by the IBS business unit. In developing boarding school holding and preparing the standardization of IBS financial statements with the IBS accounting system used by the boarding school business unit, Bank Indonesia in collaboration with IAI prepared IBS Accounting Guidelines which were effective on 31 May 2018.

Based on the data base for IBS in the Ministry of Religion until 2019, there are 29 IBS with approximately 7700 students. IBS are non-profit organizations, namely organizations that obtain their own capital or fund capital by increasing surpluses, accepting donations or assistance for individual donations or community groups. The non-profit organizations necessary to notice their financial statements because they are used to assess the organization ability to provide services, the ability to continue to provide services and the way the organization carries out responsibility for its performance. The problem is that the IBS in Indonesia have not all compiled financial reports in accordance with accounting standards, in terms of accountability for financial reports, internal and external IBS are needed as well as the Creator.

The problem is that the IBS in Indonesia have not all of them established reporting their financial statements based on the IBS Accounting Guidelines which were effectively used on May 31, 2018, so the problem formulation in this study is how to implement the IBS accounting guidelines in improving the quality of financial reports of the Al Mujaddadiyyah IBS in Indonesia.

\section{Theory}

\subsection{IBS Accounting Guidelines}

The IBS Accounting Guidelines, which became effective on 28 May 2018, were made as a form of economic empowerment in Indonesia [2]. These guidelines are very helpful in financial management at IBS. IBS Accounting Guidelines (PAP) Reference The main reference for the preparation of IBS financial reports is the Financial Accounting Standards for Entities without Public Accountability (SAK ETAP) issued by the IAI Financial Accounting Standards Board. IBS Accounting Guidelines (PAP) prepared by Bank Indonesia and IAI using the following references:

a. SAK ETAP issued by the IAI Financial Accounting Standards Board;

b. Islamic PSAK and ISAK issued by the IAI Sharia Accounting Standards Board. 
If the Financial Accounting Standards provide a choice of accounting treatment, the preparation of IBS financial statements follows the provisions chosen in this IBS Accounting Guidelines. In the event of a conflict between the provisions of the IBS Accounting Guidelines and the provisions of the applicable Financial Accounting Standards, the financial statements of the IBS must follow the provisions of the Financial Accounting Standards.

\section{a) Presentation of IBS Financial Statements Based on IBS Accounting Guidelines}

Purpose of Financial Statements The objectives of the financial statements prepared and presented by the boarding school foundation are:

1) Provide information about financial position, performance, cash flow and other information that is useful for users of financial statements in order to make economic decisions

2) The form of responsibility of the boarding school foundation for the use of the resources entrusted to him.

\section{b) Accounting Policies}

Based on the IBS Accounting Guidelines, the accounting policies of IBS should reflect the principle of prudence and cover all material matters and in accordance with the provisions of SAK ETAP.

In the event that SAK ETAP has not specifically regulated the issue of recognition, measurement, presentation or disclosure of a transaction or event, the board of the boarding school foundation must establish a policy to ensure that the financial statements present information that:

1) Relevant to the needs of users of financial statements for decision making

2) Reliable, with understanding

3) Presenting honestly the financial position, financial performance and cash flow of the boarding school foundation

4) Describes the economic substance of an event or transaction and not merely its legal form

5) Neutral, which is free from partiality

6) Reflects caution

7) Includes all material things In establishing these accounting policies, it must consider:

1) Requirements and guidance in SAK ETAP relating to similar matters

2) Definition, recognition criteria and measurement concepts of income, expenses, assets and liabilities, in the Pervasive Concepts and Principles of SAK ETAP

3) Requirements and guidance in IFRS relating to similar and related issues.

\section{c) Financial Statements Presentation and Components}

The financial statements present the financial position, performance and the cash flow of the boarding school foundation fairly, along with the required accordance disclosures with some applicable regulations. The SAK used as a reference in the preparation of IBS Accounting is SAK ETAP No: 45 regarding the financial statements produced by non-profit entity. Based on the IBS Accounting Guidelines, complete financial statements from the boarding school foundation consist of: 
1) Statement of Financial Position. It provides about information to regard the assets, net assets and liabilities of the IBS foundation, as well as the relationship between these elements at a certain time. Assets are presented based on their characteristics and classified into current assets and non-current assets, Liabilities are presented in order of maturity and classified into short-term liabilities and long-term liabilities.

2) Activity Report. It provides information about the financial performance of the boarding school foundation during a certain reporting period. Activity reports provide information about the transactions effects and other condition that can change the amount of net-assets, transactions relation, and how the resources used to implement various programs or services.

3) Cash Flow Statement. It provides information on cash receipts and payments from IBS foundations during a certain reporting period. Cash and cash equivalents are classified into cash flows from operations, investing and financing. The cash flows from operations are presented using the indirect method.

4) Notes to Financial Statements. It must be presented in a systematic manner in the order of presentation according to the main components of the financial statements that are an integral part of the financial statements. It relates to items in the financial position statements, activity reports and cash flow statements which provide explanations, both qualitative and quantitative in nature.

5) Materiality and Reporting Period

The boarding school foundation financial statement is based on the concept of materiality. Items that are material in number are presented separately in the financial statements, while items that are immaterial can be combined as long as they have a similar nature or function. Information is considered material if the failure to include, or errors in recording, the information can affect decisions taken. The financial statements of the boarding school foundation are presented annually based on the hijriah or AD years. In the case of a new IBS foundation established, the financial statements can be presented for a period shorter than one year.

\subsection{Non-Profit Organization}

A non-profit organization is an organization whose main objective is to support a matter in attracting public attention or public service for a non-commercial purpose, without any attention to things that are for profit. Non-profit organizations include houses of worship, public schools, foundations, etc.

It is an organization whose main objective is to support the matter in attracting public attention for a non-commercial purpose, without any attention to profit-seeking matters [3]. Non-profit organizations include public charities, public hospitals and clinics, churches, public schools, community assistance, political organizations with legislation, voluntary service organizations, trade unions, professional associations, research institutes, museums, and some government officials.

Non-profit organizations are one of four categories: VHWO, hospitals, colleges and universities, and other non-profit organizations [4]. From the definition above, the conclusion is that a non-profit organization is a group or organization engaged in the social sector and is not focused on looking for profit or profit. For example: foundations (hospitals, schools, universities, IBS, etc.), museums, churches, mosques, political organizations, etc.). 


\section{Method}

Population The research object used by researchers in the study was the IBS which were registered in the database of IBS in the Ministry of Religion of Madiun City. Based on the PDPP, the Madiun City Ministry of Religion consists of 29 IBS. Then from the data the researcher took the object of research using purposive sampling technique. The purposive sampling technique is one of the non-random sampling techniques, where the researcher determines the sampling technique by determining some specific characteristics that used in the research so that it is expected to solve the research problem. The research object is the Al Mujaddadiyyah IBS in Madiun.

The data analysis technique that the researchers used was qualitative descriptive analysis. Where the data obtained is described so that it can provide clarity according to the realities in the field. The following are the stages of analysis carried out in this study) are:

a) Data Reduction. Reducing data means summarizing, choosing the main things, focusing on the things that are important, looking for themes and patterns. The data will provide a clearer figure, and make it more reliable for the researcher to find out further data collection, and search for it if necessary. The data that researchers reduce is data from the results of observations, interviews and documentation methods, such as observation data related to financial recording based on IBS accounting at the Al Mujaddadiyyah IBS.

b) Data Display. The next step is to display the data. In qualitative research, data presentation can be done in the form of brief descriptions, charts, relationships between categories, flowcarts and the like. This was done in order to describe the data in order to facilitate the understanding of researchers as well as readers in analyzing financial records based on IBS accounting at Pondok Pesantren Al Mujaddadiyyah, Madiun City.

c) Conclusion and Verification. The third step and the final step according to Miles and Huberman is drawing conclusions and verification. Drawing conclusions made by researchers by collecting data from interviews, observations and documentation related to financial records based on IBS accounting at Al Mujaddadiyyah IBS, which has been reduced and presented the data [5].

\section{Result and Discussion}

Based on the results of observations, observations and interviews, the results of the descriptive data analyzed by the author show that the financial statements of the $\mathrm{Al}$ Mujaddadiyah IBS in Indonesia are managed by a foundation, namely the recapitulation of financial reports regarding income and expenditure for 1 year, from July 2019 to June 2020.

Based on financial reports managed by the foundation, the Al Mujaddadiyyah IBS in Indonesia in preparing financial reports has not yet referred to the IBS Accounting Guidelines. The process of recording and reporting financial transactions is an essential part of financial management. As for the obstacles that the boarding school has not implemented the IBS Accounting Guidelines issued by the IAI and Bank Indonesia which were effectively used as of May 312018 are:

a) Unbalanced income and expenses

b) Each unit in preparing the financial statements is in different format.

c) Each unit does not understand the IBS accounting guidelines.

The constraints experienced by the Al Mujaddadiyyah IBS, the management of the boarding school must have competent human resources in accounting and it is time to prepare 
financial reports by implementing the boarding school's accounting guidelines. IBS accounting guidelines are non-binding guidelines for IBS in preparing financial reports. IBS financial reports consist of financial position reports, activity reports, cash flow reports and notes on financial reports.

Based on the description of the income and expenditure data of the Al Mudaddadiyyah IBS for one year, from July 2019 to June 2020 (Dzulhijjah 1440-1441 H), the financial statements referring to the IBS Accounting Guidelines are made for one period with the Islamic year). The process of recording accounting starts from transaction analysis, journalizing, posting to ledgers then compiling financial reports.

\subsection{Activity Report}

The activity report contains unrestricted net assets, temporarily bound net assets and permanent net assets. The report on the activity of the Al Mujaddadiyyah IBS shows that the unrestricted net assets consist of non-binding income from contributions from students, grants from the founders and administrators of the Al Mujaddadiyyah IBS foundation, cooperatives, and the community and the free costs consist of educational expenses, accommodation expenses, and general and administrative expenses.

Permanently bound net assets are resources whose usage restrictions are retained permanently, but non-profit organizations are permitted to use part or all of the income or other economic benefits that come from these resources. Resources included in permanently bound net assets are cash waqf, movable price waqf other than money, and the net proceeds from the management and development of waqf and the allocation of the proceeds from the management and development of the waqf.

The net assets permanently tied to the Al Mujaddadiyah IBS in Indonesia are IDR $195,000,000$ for building money, IDR 22,285,000 for paving donors and IDR $175,000,000$ for renovating mosques and offices.

\subsection{Statement of Financial Position}

The objective of the statement of financial position is to provide information on current and non-current assets, liabilities and net assets, which consist of non-binding net assets, temporarily bound net assets and permanently bound net assets.

The results of the implementation in the financial position report show that the $\mathrm{Al}$ Mujaddadiyah IBS, for its fixed assets has not all been recorded and has not allocated the expense for depreciation on existing assets and trade receivables come from arrears of students.

\subsection{Cash Flow Statement}

It shows the receipts and disbursements of cash and cash equivalents during a certain period which are grouped into operating activities, investing activities and financing activities. The author concluded that the cash flow statement for the Al Mujjadadiyah IBS in Indonesia includes:

a) The cash flows from operations consisted of cash from revenues of IDR 2,439,716,000 and cash disbursed for expenses of IDR 1,643,000,000 
b) The cash flows from investments consisted of purchases of fixed assets of IDR $171,000,000$, purchases of intangible fixed assets of IDR 32,280,000 and purchases of other non-current assets of IDR 18,000,000.

Cash flow from funding consists of 1) boss funds IDR 230,800,000,2) building donation funds IDR 195,000,000, 3) mosque and office rehabilitation assistance IDR 175,000,000,4) cottage donations IDR 51,000,000, 5) profit sharing for stalls IDR 2,500,000,6) donation of paving from donors IDR $22,285,000,7)$ donation of paving for final dormitory IDR $18,000,000,8)$ infaq for teachers IDR $8,800,000,9)$ long-term debt of IDR $60,000,000$ and 10) Long-term debt of IDR $528,585,000$.

\subsection{Notes to Financial Statements}

It contain statements about how the financial statements of the Al Mujjadadiyah IBS in Indonesia are compliant with the IBS's accounting guidelines in compiling notes on the financial statements containing the latest summary of accounting policies that explain material important posts related to the financial statements of the Al-Mujjadadiyah IBS.

Limitations in implementing IBS accounting guidelines at the Al Mujjadadiyah IBS in Indonesia in July 2019 or 29 Dzulhijjah 1440 Hijrah are financial statement data in one year or period and fixed assets which include land, buildings, vehicles and so on have not been recorded in detail in the financial statements but recorded in the inventory section.

\section{Conclusion}

Based on the results and discussion, the authors draw the following conclusions:

a) The financial reports of the Al-Mujjadadiyah IBS in Indonesia include expenses and income and human resources. There is still a lack of understanding of the Islamic boardimg school's accounting guidelines.

b) The Al-Mujjadadiyah IBS in Indonesia has not recorded its assets in its financial statements, so the financial statements have not allocated depreciation expense to its assets. IBS financial reports that are prepared include formal education activities (SMP, MA, SMK) and IBS or foundations, for other business activities separate financial reports.

\section{References}

[1] C. Paramaesti, "Revolusi Industri 4.0, Menteri Perindustrian Gandeng Pesantren," TEMPO.CO, 2018. https://bisnis.tempo.co/read/1088373/revolusi-industri-4-0-menteriperindustrian-gandeng-pesantren (accessed May 12, 2020).

[2] IAI, Pedoman Akuntansi Pesantren. Jakarta: Bank Indonesia, 2018.

[3] A. N. M. Tinungki and Rudi, "Penerapan Laporan Keuangan Organisasi Nirlaba Berdasarkan PSAK No.45 Pada Panti Sosial Tresna Werdha Hana,” J. Ris. Ekon., vol. 2, no. 2, 2014.

[4] P. R. Andarsari, "LAPORAN KEUANGAN ORGANISASI NIRLABA (LEMBAGA MASJID)," J. Ekon. Univ. Kadiri, vol. 1, no. 2, 2016.

[5] Sugiyono, Metode Penelitian Kuantitatif Kualitatif dan R\&D. Bandung: Alfabeta, 2017. 